\title{
RURAL ECONOMY: A GEOGRAPHICAL DISTRIBUTION OF SCIENTIFIC DISCOURSE
}

Maria RIVERA, candidate on Sustainable Rural Development at the Agroforestry Department of the Technical University of Madrid (UPM), Escuela Superior de Ingenieros Agónomos, Av. Complutense s/n, Spain, maria.rivera@upm.es (corresponding author) Alina SEEBACHER, Agroforestry Department of the Technical University of Madrid (UPM), Escuela Superior de Ingenieros Agónomos, Av. Complutense s/n, Spain, alina.seebacher@.gmail.com

José Maria DIAZ PUENTE, Rural Development and Prof from the Agroforestry Department of the Technical University of Madrid (UPM), Escuela Superior de Ingenieros Agónomos, Av. Complutense s/n, Spain, jm.diazpuente@upm.es

In the political system and in public perception, the well-functioning of economy is frequently equalled to the output of the national economy-that is, the Gross Domestic Product (GDP). However, during the last decades, this narrow conception of economic prosperity started to erode. This paper describes the scientific discussion surrounding the topic of "economy" in rural places, with the objective of exploring who is setting the agenda and which themes are prevalent. We examine 102 journal papers published during the last decade and design a methodological frame based on Nvivo10 software which combines quantitative analysis of geographical attributes (geographical location; journal's precedence; author's institution) and qualitative content analysis of the selected articles. Our results put forward that "rural economy" is conceptually linked to different societal spheres in areas such as development and progress, society and community, resources and sustainability. However, it is authors coming from developed countries the ones that mainly treat this issue and base their studies mainly on developing countries. Therefore it can be concluded that scientific discourse around rural economy deals with issues of interest to developed countries, but that it has, however, started to get linked to social and environmental aspects, and it is through achieving a balance between them that rural prosperity will be achieved.

Keywords: content analysis; geographical distribution; prosperity; rural economy; scientific agenda.

\section{INTRODUCTION}

Since the Enlightenment, the concepts of development and wellbeing have been closely linked to economic, scientific, and technical dimensions. Conventionally, growth has been measured through the Gross Domestic Product (GDP) and thus translated into an increase in production and consumption of goods and services traded in the market (Baumol et al., 2007). However, since the 1970s, the dominant idea that economic growth equals development and wellbeing started to erode (Pena-Trapero, 2009). An enhanced output-that is, an increase in GDP-does not accurately represent a progress in human welfare, as it fails to account for non-market services, negative externalities and changes in the asset base affecting our future consumption possibilities (Darnhofer et al., 2014; Jackson and Anderson, 2009); neither it outlines how income and wealth are distributed among people (Stiglitz et al., 2009). Therefore, economic growth is increasingly considered merely as a necessary condition for genuine prosperity, instead of using it as a synonym for prosperity (Jackson, 2009; Stiglitz et al., 2009). As a consequence, a reformulation process of these key concepts was initiated within the public and scientific sphere and alternative definitions for progress, as well as new measurement techniques, were developed.

The realisation that non-economic aspects of prosperity are as important as economic ones incited the new goal of measuring wellbeing in a different way; a way, that recognises the multidimensionality of the concept (Chambers, 1997; Neff, 2007; Anand et al., 2005) by including important socio-cultural aspects, such as psychological wellbeing, freedom of choice, opportunities and social capital (Stiglitz et al., 2009, van der Ploeg et al., 2008, Sen, 1984); and environmental aspects, such as resource limitations and environmental degradation (Jackson, 2009; Diener and Suh, 1997, Daly, 2008).

There are different indicators recently created to assess general wellbeing at the national level (GPI, Legatum Prosperity Index, HDI, and Maryland's Genuine Progress Indicator). However, an index that specifically evaluates wealth in rural areas has not yet been created. Sen (1984) describes prosperity as a construct integrating three relevant dimensions and includes material satisfaction, utility, and the capability of flourishing and functioning within the specific context in his analysis. Accordingly, prosperity can be looked at as a qualitative condition defined by inclusion in a society that distribution, and reproduction in any medium, provided the original author and source are credited. 
offers opportunities, aspirations and comfort (Sardar, 2007). Thus, the circumstances that drive prosperity strongly depend on the specific context and the nature of the examined society (Collomb et al., 2012; Jolly, 2002; Rahman et al., 2005). These theoretic ideas suggest that the rural context is individuated due to its particular characteristics and dynamics, as well as its difference in functioning compared to urban societies (van der Ploeg et al., 2008). The concept of rural economy is important because eight out of ten of the world's working poor live in rural areas where the lack of decent work opportunities is prevalent. Common constraints to unleashing the potential of rural economies include: lack of decent jobs and reliable incomes; low productivity; informality; weak enforcement of the rule of law; ineffective organization and participation of rural people in decision-making; under-investment in agriculture, non-farm rural employment and infrastructure; and limited or no access to social protection and services (ILO, 2008). We want to shed light on prosperity in the specific context of rural societies and examine, up to which point the discourse around the economic dimension of prosperity is cross-connected, defined by, and based on other societal dimensions. With this aim, we explore the debate around "rural economy" held by the scientific elite during the last decade. In general we want to know: Who is talking about rural economy and what are they talking about? Consequently, we pursue two objectives: Firstly, we explore, which voices are setting the scientific agenda; and secondly, we analyse the diversity of themes constituting this topic. To pursue the goal of our research, 102 articles published within the period from 2004 to 2014 and dealing with "rural economy" were analysed.

Our intention is to contribute to a better understanding of the dimensions constituting "economy" in rural places, as considered by the scientific system. We believe that this analysis adds to the broader objective of redefining prosperity and setting bounds to the shortage of classical economic wellbeing measurements: By exploring the themes present in those articles, we try to discover, which other dimensions are closely related to "rural economy", and thus should be considered when defining (and measuring) rural prosperity.

\section{METHODOLOGY}

In this study, a methodological framework for understanding the scientific debate surrounding "rural economy" is developed by applying three rigorously designed procedures: (1) article selection, (2) quantitative attribute analysis and (3) qualitative content analysis of the abstracts using NVivo 10 software.

A search within ISI Web of Science was performed, giving as a result 102 journal papers published during the last decade (2004-2014, April) containing the terms "rural" and "economy" in the title. This search was restricted to the Science Citation Index Expanded and the Social Sciences Citation Index with the purpose of identifying high-impact articles published in indexed and peer-reviewed journals. All articles that met the conditions were extracted. The following attributes were automatically retrieved from ISI Web of Science and imported into NVivo 10: publication year, publication name, country of the academic institution to which the first author is affiliated (country of author), country of the journal's editorial (Díaz-Puente et al., 2007). Besides, the attribute "geographic study area" was introduced and determined for each article. Additionally, for each country of journal, author and study area, its continent and status as developing or developed country (International Statistical Institute, 2014) was specified. Each attribute was analysed separately and in combination with the other attributes.

In order to obtain a consistent idea of the main contents treated within the articles (note that only 94 articles provided abstracts), a methodological framework combining inductive and quantitative approaches of content analysis was developed. The central idea of qualitative content analysis is that "the many words of the text are classified into much fewer content categories" (Weber, 1990, p. 12) through a systematic process of identifying themes and patterns. Hence, the objective is to find relevant themes (also called codes or categories) present in the text material (Ryan and Bernard, 2003).

\section{Who is Talking: a Basic Quantitative Analysis}

In this section, we provide a quantitative description of the basic attributes of the 102 articles. We concentrate on the voices that shape the academic discourse about "rural economy" and on the institutions that carry those voices.

Geographic Study Area

Most of the articles $(60 \%)$ explicitly examine issues of developing countries, whereas only one third refers to developed countries (see Table 1). Concerning the continents of the study areas, an Asian (35\%) or European setting $(29 \%)$ is prevalent, followed by Africa, North-America and then, Latin-America.

With respect to specific countries, Table 1 shows that 16 articles examine rural economy in China, evidencing that $44 \%$ of the papers about Asia concentrate on China. Similarly, the USA constitutes an important research area (6 articles explore topics concerning the USA). Europe's geographic areas (30 articles) are more widespread, with minor concentrations on England (17\% of the European articles), France and Scotland (each $10 \%$ of the European studies). Interestingly, nearly $60 \%$ of the articles about Africa examine four countries (Malawi, Ghana, Nigeria and South Africa).

Origin of Authors

Most of the first authors are affiliated to academic institutions in developed countries (81\%), indicating that publishing activity is higher in the global North. More specifically, most of the authors proceed from Europe (40\%), North-America (34\%) and-to a lesser extent-Asia (15\%).

Table 1 shows the origin of the authors in detail. Remarkably, nearly $30 \%$ come from institutions located in the USA, whereas $16 \%$ come from England. In total, more than $60 \%$ of the authors proceed from English-speaking countries, evidencing an Anglo-Saxon prevalence in the examined scientific community. Interestingly, only 5 authors come from Chinese institutions (compared to 16 articles dealing with Chinese issues). 
Distribution of Scientific Journals

The editorials of the scientific journals publishing in the field of "rural economy" are even more concentrated: $94 \%$ of the journals are set in the global North. Table 1 shows the prevalence of European (64\%) and North-American (30\%) journals. Concerning Europe, the publications proceeding from England and the Netherlands represent $88 \%$ of the European publications (65) and $56 \%$ of the total publications (102). About $78 \%$ of the articles were published in editorials from English-speaking countries. To summarise, the prevalence of publications and-to a lesser extent-of authors proceeding from developed countries is evident. In contrast, only one third of the geographic study areas are located in the global North.

Geographic areas treated in selected articles

As can be seen in table 1, 59.8\% of the articles talk about developing countries, and only $34.3 \%$ about developed ones. Being more specific, Asia received the most attention with $35.3 \%$ of the articles, out of which $15.7 \%$ talked about China. Followed by articles that talk about Europe (29.4\%) in general, which come next with $17.6 \%$ of the total. Africa goes next with $13.7 \%$ of the articles talking about countries located in this continent and finally North and Latin America with respectively $7.8 \%$ and $4.9 \%$.

Table 1. Geographic distribution of attributes

\begin{tabular}{|c|c|c|c|c|c|c|c|c|c|}
\hline & \multicolumn{3}{|c|}{ Geographic Areas } & \multicolumn{3}{|c|}{ Countries of Author } & \multicolumn{3}{|c|}{ Countries of Journal } \\
\hline & $\begin{array}{l}\text { No. } \\
\text { Art. }\end{array}$ & $\begin{array}{c}\% \\
\text { (total) }\end{array}$ & $\begin{array}{c}\% \\
\text { (continent) }\end{array}$ & $\begin{array}{l}\text { No. } \\
\text { Art. }\end{array}$ & $\begin{array}{c}\% \\
\text { (total) }\end{array}$ & $\begin{array}{c}\% \\
\text { (continent) }\end{array}$ & $\begin{array}{l}\text { No. } \\
\text { Art. }\end{array}$ & $\begin{array}{c}\% \\
\text { (total) }\end{array}$ & $\begin{array}{c}\% \\
\text { (continent) }\end{array}$ \\
\hline Developing & 61 & 59.8 & & 19 & 18.6 & & 6 & 5.9 & \\
\hline Devloped & 35 & 34.3 & & 83 & 81.4 & & 96 & 94.1 & \\
\hline Not Defined & 6 & 5.9 & & & & & & & \\
\hline Africa & 14 & 13.7 & 100.0 & 4 & 3.9 & 100.0 & 2 & 2.0 & 100.0 \\
\hline Malawi & 2 & 2.0 & 14.3 & 1 & 1.0 & 25.0 & & & \\
\hline Ghana & 2 & 2.0 & 14.3 & & & & & & \\
\hline Nigeria & 2 & 2.0 & 14.3 & 1 & 1.0 & 25.0 & 1 & 1.0 & 50.0 \\
\hline $\begin{array}{l}\text { South } \\
\text { Africa }\end{array}$ & 2 & 2.0 & 14.3 & 1 & 1.0 & 25.0 & 1 & 1.0 & 50.0 \\
\hline Other & 6 & 5.9 & 42.9 & 1 & 1.0 & 25.0 & & & \\
\hline Asia & 36 & 35.3 & 100.0 & 15 & 14.7 & 100.0 & 3 & 2.9 & 100.0 \\
\hline China & 16 & 15.7 & 44.4 & 5 & 4.9 & 33.3 & & & \\
\hline Other & 20 & 19.6 & 55.6 & 10 & 9.8 & 66.7 & 3 & 2.9 & 100.0 \\
\hline Australia & & & & 6 & 5,9 & & & & \\
\hline Europe & 30 & 29.4 & 100.0 & 41 & 40.2 & 100.0 & 65 & 63.7 & 100.0 \\
\hline England & 5 & 4.9 & 16.7 & 16 & 15.7 & 39.0 & 46 & 45.10 & 70.8 \\
\hline Scotland & 3 & 2.9 & 10.0 & 3 & 2.9 & 7.3 & 1 & 1.0 & 1.5 \\
\hline France & 3 & 2.9 & 10.0 & 1 & 1.0 & 2.4 & & & \\
\hline Netherlands & 1 & 1.0 & 3.3 & 1 & 1.0 & 2.4 & 11 & 10.78 & 16.9 \\
\hline Other & 18 & 17.6 & 60.0 & 20 & 19.6 & 48.8 & 7 & 6.9 & 10.8 \\
\hline Latin-America & 5 & 4.9 & & 1 & 1.0 & & 1 & 1.0 & \\
\hline North-America & 8 & 7.8 & 100.0 & 35 & 34.3 & 100.0 & 31 & 30.4 & 100.0 \\
\hline USA & 6 & 5.9 & 75.0 & 30 & 29.4 & 85.7 & 31 & 30.4 & 100.0 \\
\hline Canada & 2 & 2.0 & 25.0 & 5 & 4.9 & 14.3 & & & \\
\hline $\begin{array}{l}\text { English } \\
\text { Speaking }\end{array}$ & 18 & 17.6 & & 64 & 62.7 & & 79 & 77.5 & \\
\hline
\end{tabular}

Origin of Authors versus Study Areas

Examining the academic institutions of the first authors writing about each geographic study area, it is noticeable that generally, authors prefer to write about issues concerning their home continents (see diagonal in Figure 1). African and Asian authors exclusively choose research questions regarding their continents. European authors also mostly deal with their own continent ( 25 out of 38). Only authors from North-American institutions investigate more on an Asian setting (13 out of 30 ) than on their home countries. Figure $2 b$ condenses this outcome: No author coming from institutions in the global South explores issues in developed countries, whereas authors from the global North write more about developing (42 articles) than developed (35 articles) regions. 
What's Talked About: a Qualitative Content Analysis

The topics included within the literature dealing with "rural economy" are multiple and diverse. The methodology described in section 2 allowed us to separate seven content categories.

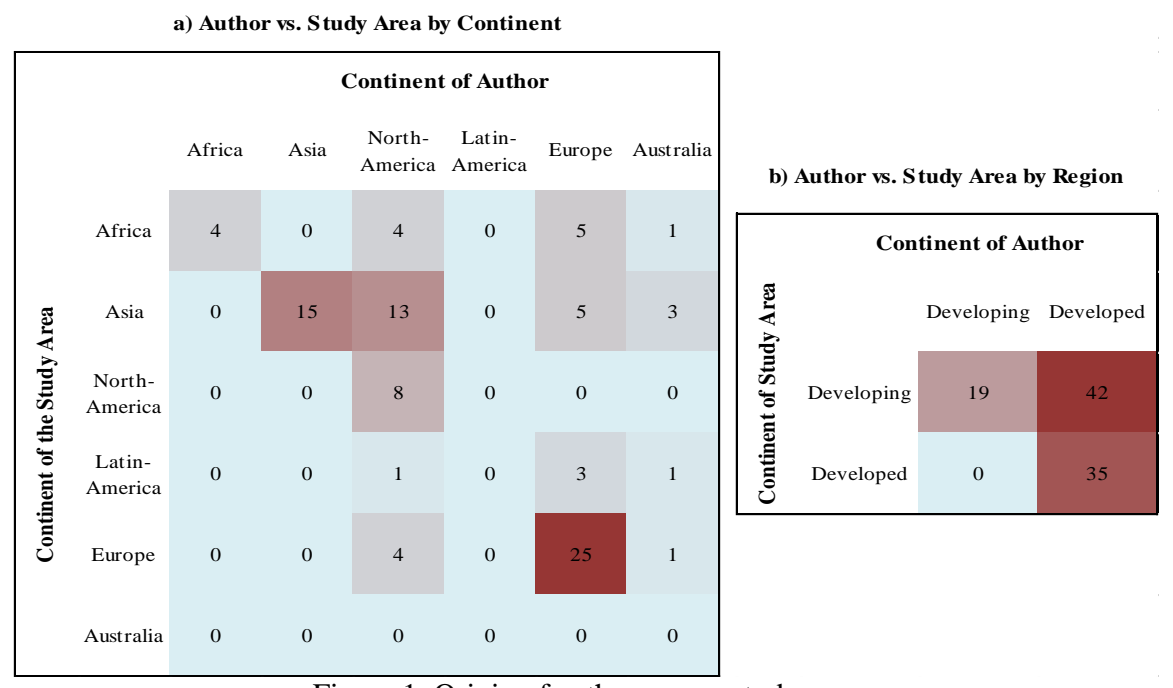

Figure 1. Origin of author versus study area

Note: Number of articles for a) the continents and b) the regions of authors and study areas. Dark red indicates a high amount of articles in this study area, whereas light blue signifies a low number (Source: Own elaboration)

\section{Content Categories}

Parallel to the levels of analysis, we established seven contents categories (see Table 2): Category 1 "Progress \& Development" contains more than half of the articles (48 out of 94). At the micro-level, the concept of development is often equalled to income and access to food ( 23 articles), whereas at the other levels the themes are more diverse: Those articles refer to the social, economic, territorial and ecological dimensions of rural development.

Table 2. Content categories

\begin{tabular}{|c|c|c|c|}
\hline & Content Categories & No. Art. & $\%$ (total) \\
\hline 1 & Progress \& Development & 48 & 51.1 \\
\hline 2 & Neoliberal Classical Economy & 45 & 47.9 \\
\hline 3 & Resources \& Capital & 44 & 46.8 \\
\hline \multirow[t]{4}{*}{4} & Society and Community & 36 & 38.3 \\
\hline & Politics \& Public Regulation & 33 & 35.1 \\
\hline & Alternative Economy & 27 & 28.7 \\
\hline & Sustainability & 12 & 12.8 \\
\hline 5 & Total & 94 & 100.0 \\
\hline
\end{tabular}

Source: Own elaboration

The "Classical Neoliberal Economy" category refers to concepts present in mainstream economic literature. In total, nearly half of the articles about rural economy (45 out of 94) relate to classical economic concepts. They are divided into three normative positions: On the one hand, almost two thirds of the authors (29 out of 45) write in a neutral or positive way and evaluate specific situations from a classical economic viewpoint. On the other hand, one third of the authors (16 out of 45) highlight the negative aspects of our current economic system and do not examine those situations in narrow terms of success or failure, but focus on the underlying premises. To a lesser extent, this category also deals with management aspects ( 9 out of 45 ).

The third category "Resources \& Capital" encloses a totality of 44 articles and can be separated into three subcategories: 21 articles address the significance of social and human capital; the same amount of articles discuss the relation between economic activities and natural, physical or environmental resources; finally, the infrastructural and technological basis for rural development is explored (17 out of 44).

Category 4 "Society \& Community" includes $38 \%$ of the articles (36 out of 94) and deals above all with three fundamental research topics: gender issues (eight articles describe how gender influences occupational and educational possibilities), migration and its effects on the left-behind regions or households (seven articles) and socio-economic inequality across population (12). 
The fifth category "Politics \& Public Regulation" contains more than one third of the articles (33 out of 94) and generally examines existing political structures, concrete challenges for policy-makers and social consequences of policies. Within this category, one topic is noteworthy: In total, six authors address the difficulties faced by governments when delivering public services and comment the actual trend of involving other, non-public actors in this task.

The "Alternative Economy" category focuses on economic structures other than classical agriculture and forestry. Key-topics within this category are small-scale enterprises, rural non-farm activities, diversification of economic activities and innovation. In total, more than a quarter of the articles (27 out of 94) were included within this category. All articles either analyse alternative economy objectively (abstaining from a normative judgment) or consider it as something positive enhancing rural development.

Regarding the "Sustainability" category, 12 articles (out of 94) articulate mechanisms that contribute to sustainable development, shed light on sustainable resource management or highlight the frictions between the sustainability paradigm and other societal influences.

\section{CONCLUSIONS}

In this paper, we designed and applied a methodological frame to examine the selected text material representing the academic discourse surrounding "rural economy". This allowed us to contribute to a better understanding of the main themes and the scientific actors shaping the debate. Drawing conclusions, we have to bear in mind that this analysis was based on a predefined selection of articles and thus the results cannot be mistaken for the general scientific opinion.

Concerning the major results, the quantitative attribute analysis showed a significant prevalence of developed countries in publication activity: The majority of the first authors are affiliated to European or North-American institutions; with respect to the journal editorials, this unequal distribution is even more pronounced. In consequence, those outcomes evidence a one-sided (or north-sided) scientific activity and indicate that the debate about "rural economy" is biased towards a European and North-American perspective. At the same time, the geographical areas treated by these authors are mainly located in developing countries. Considering the importance research has on development, it could be argued that this is some kind of "scientific colonialism". To achieve a balanced scientific agenda-setting and the integration of geographically different concerns, a more equal scientific activity across North and South is necessary. On the other hand, content categories demonstrate how the concept of rural economy is linked to different ideas that not only relate to GDP such as sustainability, alternative economies, community and society and resources for development. It can therefore be concluded that scientific discourse around rural economy is already associated to social and environmental aspects, and that it is through achieving a balance between them that rural prosperity will be achieved. However, a new definition of prosperity that includes these three aspects should be globally created and approved so that policies can be shaped in order to attain this newer and completer conception of the term. The objective of this research for the future is to analyse further in depth the content of the articles in order to better answer the question of what is the scientific community concerned about in relation to rural economy, as well as which themes are important in which geographical areas.

\section{REFERENCES}

1. Anand, P., Hunter, G., Smith, R. 2005. Capabilities and Well-being: Evidence based on the Sen-Nussbaum Approach to Welfare. Social Indicators Research, Vol. 74, pp. 9-55. http://dx.doi.org/10.1007/s11205-005-6518-Z

2. Baumol, W. J., Litan, R. E., Schramm, C. J. 2007. Good Capitalism, Bad Capitalism, and the Economics of Growth and Prosperity, Law and Economics Workshop. Yale University Press, New Haven \& London. http://dx.doi.org/10.2139/ssrn.985843

3. Bazeley, P. 2006. The Contribution of Computer Software to Integrating Qualitative and Quantitative Data and Analyses. Research in the Schools, Vol. 13, Iss. 1, pp. 64-74.

4. Booth, W. C., Colomb, G. G., Williams, J. M. 2008. The Craft of Research, Third. ed. University of Chicago Press, Chicago. http://dx.doi.org/10.7208/chicago/9780226062648.001.0001

5. Chambers, R. 1997. Editorial: Responsible Well-being-a Personal Agenda for Development. World Development, Vol. 25, Iss. 11, pp. 1743-1754. doi:10.1016/S0305-750X(97)10001-8

6. Collomb, J.-G. E., Alavalapati, J. R., Fik, T. 2012. Building a Multidimensional Wellbeing Index for Rural Populations in Northeastern Namibia. Journal of Human Development and Capabilities: A Multi-Disciplinary Journal for People-Centered Development, Vol. 13, Iss. 2, pp. 227-246. http://dx.doi.org/10.1080/19452829.2011.645532

7. Daly, H. 2008. A Steady-State Economy: A Failed Growth Economy and a Steady-State Economy are not the same thing; they are the very Different Alternatives we face. Sustainable Development Commission, London.

8. Daly, H., Cobb, J., Cobb, J. B. 1989. For the Common Good-Redirecting the Economy towards Community, the Environment and Sustainable Development. Green Print, London.

9. Darnhofer, I., de los Rios, I., Knickel, K., Koopmans, M., Lamine, C., Olsson, G.A., de Roest, K., Rogge, E., Sumane, S., Tisenkopfs, T. 2014. Rethinking the Links between Farm Modernisation, Rural Development and Resilience in a World of Increasing Demands and Finite Resources. University of Life Sciences, Vienna.

10. Díaz-Puente, J. M., Cazorla, A., Dorrego, A. 2007. Crossing National, Continental, and Linguistic Boundaries Toward a Worldwide Evaluation Research Community in Journals of Evaluation. American Journal of Evaluation, Vol. 28, Iss. 4, pp. $399-415$. $\underline{\text { http://dx.doi.org/10.1177/1098214007308413 }}$ 
11. Diener, E., Suh, E. 1997. Measuring Quality of Life: Economic, Social and Subjective Indicators. Social Indicators Research, Vol. 40, Iss. 1, pp. 189-216. http://dx.doi.org/10.1023/A:1006859511756

12. Edge, D. 1995. Reinventing the Wheel, in: Jasanoff, S., Markle, G.E., Peterson, J.C., Pinch, T. (Eds.), Handbook of Science and Technology Studies. SAGE Publications, Thousand Oaks (CA), pp. 3-24. http://dx.doi.org/10.4135/9781412990127.n1

13. Golinski, J. 2008. Making Natural Knowledge: Constructivism and the History of Science, with a new Preface. University of Chicago Press.

14. Hsieh, H.-F., Shannon, S. E. 2005. Three Approaches to Qualitative Content Analysis. Health Policy \& Services, Vol. 15, Iss. 9 , pp. 1277-1288. http://dx.doi.org/10.1177/1049732305276687

15. International Statistical Institute, 2014. International Statistical Institute: Developing Countries, URL http://www.isiweb.org/component/content/article/5-root/root/81-developing (accessed 4.17.14).

16. ILO, 2008. 97th Session of the International Labour Conference. http://www.ilo.org/ilc/ILCSessions/97thSession/lang-en/index.htm

17. Jackson, T. 2009. Prosperity Without Growth: Economics for a Finite Planet. Earthscan, London.

18. Jackson, T., Anderson, V. 2009. Redefining Prosperity-Essays in Pursuit of a Sustainable Economy. Sustainable Development Commission. Earthscan, London.

19. Jolly, R. 2002. Statisticians of the World Unite: The Human Development Challenge Awaits. Journal of Human Development, Vol. 3, Iss. 2, pp. 263-272. http://dx.doi.org/10.1080/14649880220147347

20. Legatum Prosperity Index. 2013. Prosperity Index, URL http://www.prosperity.com/\#!/ (accessed 10.21.14).

21. Luckmann, T., Berger, P. L. 1991. The Social Construction of Reality: A Treatise in the Sociology of Knowledge. Penguin, UK.

22. Maryland's Genuine Progress Indicator-An Index for Sustainable Prosperity, s.a. Maryland: Smart, Green \& Growing, URL http://www.dnr.maryland.gov/mdgpi/ (accessed 9.15.14).

23. Midgley, J. 2014. Social Development: Theory and Practice. SAGE, London.

24. Namey, E., Guest, G., Thairu, L., Johnson, L. 2007. Data Reduction Techniques for Large Qualitative Data Sets, in: Guest, G., MacQueen, K.M. (Eds.), Handbook for Team-Based Qualitative Research. Rowman Altamira, pp. 137-161.

25. Neff, D. F. 2007. Subjective Well-being, Poverty and Ethnicity in South Africa: Insights from an Exploratory Analysis. Social Indicators Research, Vol. 80, Iss. 2, pp. 313-341. http://dx.doi.org/10.1007/s11205-005-5920-x

26. Oreskes, N. 2004. The Scientific Consensus on Climate Change. Science 3, Vol. 306, No. 5702, pp. 1686-1686. http://dx.doi.org/10.1126/science.1103618

27. Pena-Trapero, B. 2009. La medición del Bienestar Social: una Revisión Crítica. Estudios de Economia Aplicada, Vol. 27, Iss. 2, pp. 299-324. (In Spain)

28. Rahman, T., Mittelhammer, R. C., Wandscheider, P. 2005. Measuring the Quality of Life across Countries: A Sensitivity Analysis of Well-being Indices (No. 2005/06). Research Paper, UNU-WIDER, United Nations University (UNU).

29. Richards, L. 2002. Qualitative Computing-a Methods Revolution? International Journal of Social Research Methodology, Vol. 5, Iss. 3, pp. 263-276. http://dx.doi.org/10.1080/13645570210146302

30. Ryan, G. W., Bernard, H. R. 2000. Data Management and Analysis Methods, in: Denzin, N.K., Lincoln, Y.S. (Eds.), Handbook of Qualitative Research. Sage, Thousand Oaks CA, pp. 769-802.

31. Ryan, G. W., Bernard, H. R. 2003. Techniques to Identify Themes. Field Methods, Vol. 15, Iss. 1, pp. 85-109. http://dx.doi.org/10.1177/1525822X02239569

32. Ryan, G. W., Weisner, T. 1996. Analyzing Words in Brief Descriptions: Fathers and Mothers describe their Children. Cultural Anthropology Methods Journal, Vol. 8, Iss. 3, pp. 13-16.

33. Sardar, Z. 2007. Prosperity: A Transmodern Analysis, Think-piece for the SDC seminar Visions of Prosperity. Sustainable Development Commission.

34. Sen, A. 1984. The Living Standard. Oxford Economic Papers, Vol. 36, pp. 74-90.

35. Stiglitz, J., Sen, A., Fitoussi, J. P. 2009. The Measurement of Economic Performance and Social Progress Revisited. Reflections and Overview. Commission on the Measurement of Economic Performance and Social Progress, Paris.

36. Talberth, J., Cobb, C., Slattery, N. 2007. The Genuine Progress Indicator 2006, Redefining Progress. Oakland (CA).

37. United Nations Development Programme, 1990. Human Development Report 1990. Oxford University Press, New York.

38. Van der Ploeg, J. D., van Broekhuizen, R., Brunori, R., Sonnino, R., Knickel, K., Tisenkopfs, T., Oostindie, H. 2008. Towards a Framework for Understanding Regional Rural Development, in: van der Ploeg, J.D., Marsden, T. (Eds.), Unfolding Webs: The Dynamics of Regional Rural Development. Royal Van Gorcum, Assen (NL), pp. 1-28.

39. Weber, R. P. 1990. Basic Content Analysis, 2nd ed, SAGE University Papers Serie on Quantitative Applications in the Social Science. SAGE, Newberry Park CA. 